\title{
FFP2-mondmasker of chirurgisch mondkapje bij COVID-19
}

Astrid van Hylckama Vlieg, Frits Rosendaal, Dennis Mook-Kanamori

Het aantal patiënten met COVID-19 neemt in rap tempo toe. Bescherming van medisch personeel is van groot belang om de ziekte onder medisch personeel te voorkomen en continuïteit in de zorg te waarborgen. Welk mondkapje heeft dan de voorkeur voor huisartsen: een FFP2-mondmasker of een chirurgisch mondkapje? Er is hiernaar nog geen specifiek onderzoek verricht bij het coronavirus, maar bij kortdurend contact in de eerste lijn lijkt er geen verschil tussen beide te zijn. Daarnaast is het nog onduidelijk of chirurgische mondkapjes vergelijkbare bescherming bieden bij langdurig of meervoudig contact.

De beschikbaarheid van mondkapjes (chirurgische mondkapjes en FFP-mondmaskers) is in Nederland beperkt. Het NHG heeft onlangs een advies uitgebracht waarin bij luchtweg- of coronaspreekuren minimaal een FFP1-mondmasker wordt aangeraden. ${ }^{1}$ Vanwege dreigende tekorten kan het echter gebeuren dat huisartsen noodgedwongen gebruik moeten maken van chirurgische mondkapjes als zij patiënten zien met (vermoedelijk) COVID-19. Hierdoor zijn huisartsen dan mogelijk minder goed beschermd tegen infectie. De vraag is dan ook of chirurgische mondkapjes medisch personeel even goed beschermen tegen infectie met COVID-19 als FFP2-mondmaskers.

\section{ZOEKSTRUCTUUR EN RESULTATEN}

Op 6 april 2020 voerden we de volgende zoekopdracht uit in PubMed: ((“COVID-19”[Supplementary Concept] OR "severe acute respiratory syndrome coronavirus 2"[Supplementary Concept] OR ((“Coronavirus"[MeSH Terms] OR "Coronavirus Infections”[Mesh:NoExp] OR pneumonia virus*[tiab] OR cov[tiab]) OR coronavirus ${ }^{\star}$ [tiab] OR corona virus ${ }^{\star}[$ tiab] OR ncov[tiab] OR 2019ncov[tiab] OR covid19[tiab] OR “covid 19" [tiab] OR "sars cov 2"[tiab] OR sars2[tiab] OR “ncov 2019" [tiab] OR "sars coronavirus 2" [tiab] OR "sars corona virus 2 " [tiab] OR "severe acute respiratory syndrome $\operatorname{cov} 2$ "[tiab] OR “severe acute respiratory syndrome cov2" [tiab] OR severe acute respiratory syndrome $\operatorname{cov}^{\star}[$ tiab] OR cov2[tiab] OR respiratory infection OR influenza) AND mask AND (preventing OR protecting OR effectiveness) AND English[Language]). Deze zoekopdracht leverde 213 resultaten op, waaronder verschillende recente systematische literatuuronderzoeken en meta-analyses. De resultaten van de verschillende trials en observationele onderzoeken zijn tegenstrijdig, vooral vanwege beperkte onderzoeksgroottes. Bovendien zijn er geen specifieke onderzoeken over de bescherming bij COVID-19.

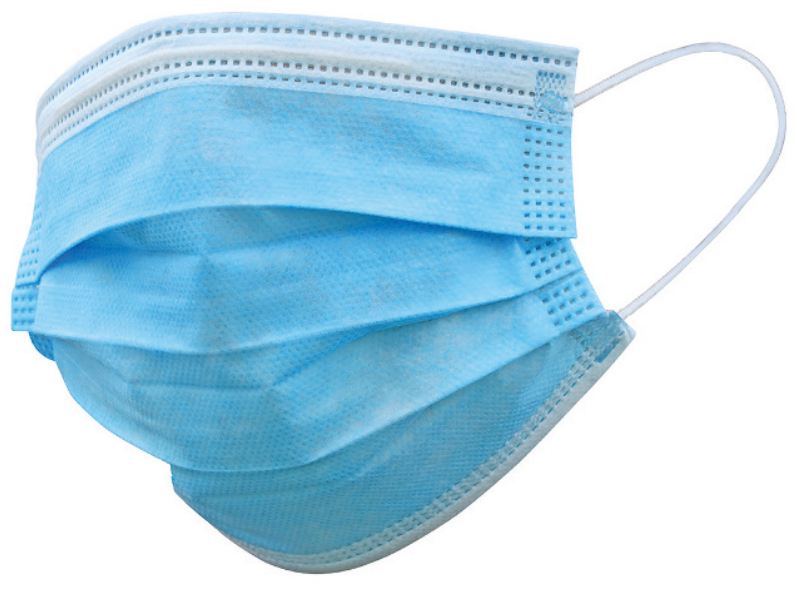

Bescherming is essentieel om de ziekte bij medisch personeel te voorkomen en continuïteit in de zorg te waarborgen. Foto: Shutterstock

In 2019 werd in JAMA een grote clustergerandomiseerde klinische trial (RCT) gepubliceerd waarin het effect werd vergeleken van chirurgische mondkapjes en FFP2-mondmaskers op de preventie van griep en andere virale luchtweginfecties onder medisch personeel. ${ }^{2}$ We behandelen deze trial van Radonovich hier, alsmede twee recente systematische literatuuronderzoeken waarin de trial werd geïncludeerd. ${ }^{2-4}$

De RCT werd uitgevoerd in diverse settings waaronder huisartsenpraktijken, tandheelkundige klinieken en eerstehulpafdelingen. Deelnemers kregen de instructie om het toegewezen masker te dragen gedurende een jaarlijkse periode van twaalf weken waarin de kans op infectie het hoogst was. Uiteindelijk analyseerden de auteurs 2512 perioden waarbij medewerkers een FFP2-mondmasker droegen en 2668 perioden waarbij medewerkers een chirurgisch mondkapje droegen. Het betrof in $70 \%$ van de gevallen medewerkers in de eerstelijns gezondheidszorg. De auteurs vonden geen verschil in risico tussen beide beschermingsmiddelen voor het optreden van infecties bij medisch personeel. Het relatieve risico op een in het laboratorium bevestigde griepinfectie en op griepachtige aandoeningen was voor dragers van FFP2-mondmaskers ten opzichte van dragers van chirurgische mondkapjes respectievelijk 1,20 (rate ratio 1,20; 95\%-BI $0,97$ tot 1,48$)$ en $0,86(95 \%-B I 0,68$ tot 1,10$)$. Ook het risico op acute luchtweginfecties in het algemeen (al dan niet in het laboratorium bevestigd) was vergelijkbaar. Tot eenzelfde conclusie komen de meta-analyses van Long en Bartoszko, die zowel de RCT van Radonovich als eerdere onderzoeken meenamen in hun analyse. ${ }^{3,4}$ In de meta-analyse van Long 
was het relatieve risico op een in het laboratorium bevestigde griepinfectie voor dragers van FFP2-mondmaskers en dragers van chirurgische mondkapjes 1,09 (95\%-BI 0,92 tot 1,28 ). Ook voor in het laboratorium bevestigde virale luchtweginfecties en andere luchtweginfecties verschilde dit risico niet: respectievelijk 0,90 (95\%-BI 0,71 tot 1,14) en 0,74 (95\%-BI 0,42 tot 1,29). In de meta-analyse van Bartozsko werd ook de conclusie getrokken dat chirurgische mondkapjes niet waren geassocieerd met een hoger risico op infectie dan FFP2-mondmaskers. De oddsratio was voor luchtweginfecties 1,06 (95\%-BI 0,90 tot 1,25) en voor klinische luchtwegaandoeningen 1,49 (95\%-BI 0,98 tot 2,28). Voor elk van deze risicoschattingen gold echter een lage bewijskracht. Slechts 1 trial analyseerde het risico op coronavirussen apart en vond hiervoor ook geen verschil tussen beide beschermingsmiddelen (infectie bij dragers FFP2-mondmaskers was $5,7 \%$ en infectie bij dragers chirurgisch mondkapjes $4,3 \%) .{ }^{5}$

\section{DE KEUZE VOOR DE HUISARTS}

Er zijn verschillende zaken belangrijk bij de interpretatie van deze getallen. Het belangrijkst is dat in de onderzoeken niet specifiek naar de bescherming tegen COVID-19 is gekeken, maar naar de bescherming tegen luchtwegklachten in het algemeen. Daarnaast is het in de meeste gevallen niet duidelijk waar de besmetting van het medisch personeel optrad. In een hoogrisicoperiode, zonder instructie voor het dragen van bescherming buiten werktijd, kan besmetting evengoed elders optreden. Daarnaast is de compliantie voor het dragen van FFP2-mondmaskers mogelijk niet gelijk aan die van chirurgische mondkapjes, aangezien deze minder comfortabel zijn. Wanneer de compliantie bij dragers van de FFP2-mondmasker lager was, verklaart dit mogelijk de afwezigheid van een verhoogde bescherming ten opzichte van chirurgische mondkapjes. De gerapporteerde compliantie in de trial van Radonovich leek echter vergelijkbaar tussen beide groepen. Ook is niet altijd duidelijk of er goede instructies zijn gegeven voor het dragen van een goed sluitend FFP2-mondmasker. Onjuist gebruik van deze maskers kan de bescherming verminderen. Laboratoriumonderzoeken lieten wel superioriteit zien van FFP2-mondmaskers ten opzichte van chirurgische mondkapjes bij influenza. ${ }^{6}$ Dit verschil verdween wanneer het FFP2-mondmasker niet goed aansloot. Daarnaast werken sommige huisartsen nu op speciaal voor COVID-19 ingerichte huisartsenposten, waar zij gedurende een dienst tientallen patiënten zien die mogelijk COVID-19 hebben. Het is onduidelijk of er in deze setting een verschil is tussen FFP2-mondmaskers en chirurgische mondkapjes.

\section{IMPLICATIES VOOR DE PRAKTIJK}

Er is nog geen specifiek onderzoek gedaan naar bescherming tegen COVID-19 en het is onduidelijk of we conclusies wat betreft de overdracht van COVID-19 kunnen vergelijken met andere virussen, zoals influenza. Van belang hierbij is of het virus door aerosolen en/of druppels wordt overgedragen. Het definitieve antwoord op deze belangrijke vraag kan echter nog jaren op zich laten wachten. ${ }^{7}$ Wat betreft de bescherming tegen luchtweginfecties in bredere zin lijkt er in de praktijk geen verschil te zijn tussen FFP2-mondmaskers en chirurgische mondkapjes bij kortdurend contact in de eerste lijn. Het is niet duidelijk of chirurgische mondkapjes vergelijkbare bescherming bieden bij langdurig of meervoudig contact, zoals op de huisartsenposten.

\section{LITERATUUR}

1. NHG. Corona: Advies PBM gespecificeerd voor de huisartsenpraktijk en de huisartsenpost. Utrecht: NHG, 2020.

2. Radonovich LJ Jr, Simberkoff MS, Bessesen MT, Brown AC, Cummings DAT, Gaydos CA, et al. ResPECT investigators. N95 respirators vs medical masks for preventing influenza among health care personnel: a randomized clinical trial. JAMA 2019;322:82433.

3. Long Y, Hu T, Liu L, Chen R, Guo Q, Yang L, et al. Effectiveness of N95 respirators versus surgical masks against influenza. A systematic review and meta-analysis. J Evid Based Med 2020 Mar 13. DOI: 10.1111/jebm.12381 [Epub ahead of print].

4. Bartoszko JJ, Farooqi MAM, Alhazzani W, Loeb M. Medical masks vs N95 respirators for preventing COVID-19 in health care workers. A systematic review and meta-analysis of randomized trials. Influenza Other Respir Viruses 2020 Apr 4. DOI: 10.1111/ irv.12745 [Epub ahead of print].

5. Loeb M, Dafoe N, Mahony J, John M, Sarabia A, Glavin V, Webby R, et al. Surgical mask vs N95 respirator for preventing influenza among health care workers: a randomized trial. JAMA. 2009;302:1865-71.

6. Noti JD, Lindsley WG, Blachere FM, Cao G, Kashon ML, Thewlis $\mathrm{RE}$, et al. Detection of infectious influenza virus in cough aerosols generated in a simulated patient examination room. Clin Infect Dis 2012;54:1569-77.

7. Lewis D. Is the coronavirus airborne? Experts can't agree. Nature 2020;580:175.

Van Hylckama Vlieg A, Rosendaal, FR, Mook-Kanamori DO. FFP2 mondmasker of chirurgisch mondkapje bij COVID-19. Huisarts Wet 2020;63[5]: 68-9. DOI: 10.1007/s12445-020-0586-9.

LUMC, afdeling Klinische epidemiologie: A. van Hylckama Vlieg, PhD, A. van_Hylckama_Vlieg@lumc.nl; F.R. Rosendaal, MD PhD, F.R.Rosendaal@lumc.nl. LÜMC, afdeling Public Health en Eerstelijnsgeneeskunde/afdeling Klinisch epidemiologie: D.O. Mook-Kanamori.

Mogelijke belangverstrengeling: niets aangegeven.

Dit is een critically appraised topic [CAT], waarbij de auteur een evidence based antwoord wil krijgen op een praktijkvraag. 